\title{
Review on Use of Plant Extracts in Weed Control
}

\author{
Shanmugalingam Srikrishnah* and Umarukatha Januha Begam \\ Department of Crop Science, Eastern University, India
}

Submission: February 25, 2019; Published: March 20, 2019

*Corresponding author: Shanmugalingam Srikrishnah*, Department of Crop Science, Eastern University, Sri Lanka, India

\begin{abstract}
Allelopathy is a natural weed control approach. It could be used without adverse effects on the environment. Allelochemicals in the plants could be used to control weeds in an environment friendly manner. Several plant extracts are used to control different weeds in many parts of the world. However commercial products of plant-based weedicides would need to be developed to obtain maximum benefits.
\end{abstract}

Keywords: Allelochemicals; Allelopathy; Weed control; Weedicides

\section{Introduction}

Weeds are important factor in agriculture, which influence crop yields. Presently, weeds have been controlled by using synthetic weedicides. These chemicals have a negative impact on the environment [1] and human health [2]. Use of allelopathy is an environment-friendly option for weed control $[3,4]$. Allelopathy is identified as a natural weed control approach $[5,6]$. Different plants have different allelochemicals. These chemicals could be utilized for suppressing weeds [7].

\section{Discussion}

It was reported that several ornamental plants have the potential to suppress growth of weeds. Nerium (Nerium oleander L.) plant extract has herbicidal activity. Nerium flower extract suppressed the growth of Italian ryegrass [8]. Al-Samarai et al. [1] reported that aqueous extract of Nerium leaves showed inhibition on the germination and seedling growth of purple nut sedge (Cyperus rotundus L.). It was reported that, Thevetia peruviana has the effect on Parthneium hysterophorus [9]. Baličević et al. [10] stated that, marigold has allelopathic effects on hoary cress. Aqueous extracts obtained from Chrysanthemum morifolium had inhibitory effects against weeds [11].

Some food crops also consist of alleopathic effects against weeds. Sorgum and maize extracts are used as organic herbicides. Randhawa et al. [7] opined that aqueous extract of sorghum at higher concentration reduced the germination of Trianthema portulacastrum. Khan et al. [12] found that, leaf water extracts of sorghum and sunflower could be used to suppress weeds in wheat cultivation during growing season. Jabran [13] reported that allelopathic potential of maize could be used for weed control. Herbaceous plants extracts also have weedicidal characters. Aqueous extract of Salvia moorcroftiana and Verbascum thapsus had weed suppressing effects [3]. Aqueous extracts of Houttuynia cordata has the ability suppress rice weeds namely Echinochloa and Monochoria [14].

Tree leaves extract also has the weed suppressing effects. It was reported that methanol extract of teak leaves could be considered as a potential pre-emergent herbicide for controlling the wild rice weeds [15]. Neem (Azadirachta indica). A. Juss) bark and leaves extracts suppressed germination and growth of Echinochloa crus-galli, Monochoria vaginalis, and Aeschynomene indi$c a L$ in a bioassay and in soil. It was also reported that concentration of phenolic compounds was higher in bark [16].

Several weedy plants extract also has herbicidal activities. Chenopodium album L. shoot residue has the ability suppress shoots and tuber formation of Cyprus esculantus [17]. Akhtar et al, [5] reported that aqueous extracts of Cirsium arvense and Ageratum conyzoides have the weedicidal activity against the weeds Phalaris minor and Poa annua.

\section{Conclusion}

There is increasing demand for plant-based herbicides. Use plant extracts in weed control is an environmentally friendly option. However, use of plant based weedcides is not much popular among farmers. Therefore, commercial products should be developed to increase their usage in Agriculture.

\section{References}

1. Al-Samarai GF, Mahdi WM, Al-Hilali BM (2018) Reducing environmental pollution by chemical herbicides using natural plant derivatives-allelopathy effect. Ann Agric Environ Med 25(3): 449-452.

2. Gasnier C, Dumont C, Benachour N, Clair E, Chagnon MC, et al. (2009) Glyphosate-based herbicides are toxic and endocrine disruptors in human cell lines. Toxicology 262(3): 184-191.

3. Arafat Y, Shahida K, Lin W, Fang C, Sadia S (2015) Allelopathic evaluation of selected plants extract against broad and narrow leaves weeds 
and their associated crops. Academia Journal of Agricultural Research 3(10): 226-234

4. Sodaeizadeh H, Hosseini Z (2012) Allelopathy an environmentally friendly method for weed control. In International Conference on Applied Life Sciences. In Tech Open.

5. Akhtar N, Javaid A, Bajwa R (2001) Herbicidal activity of aqueous extracts of Cirsium arvense and Ageratum conyzoides against weeds of wheat. Pakistan Journal of Biological Sciences 4(11): 1364-1367.

6. Khan PA, Quisar KN, Khan MA (2006) Effect of leaf extract of Populus deltoides on seed germination and seedling growth of radish, French bean and mustard. Indian Journal of Forestry 29(40): 403-406.

7. Randhawa MA, Cheema ZA, Ali MA (2002) Allelopathic effect of sorghum water extract on the germination and seedling growth of Trian thema portulacastrum. International Journal of Agriculture and Biology 4(3): 383-384.

8. Uslu ÖS, Gedik O, Kaya AR, Erol A, Khan MA (2018) Allelopathic Effects of Flower Extract of Oleander (Nerium oleander) on the Germination of Seed and Seedling Growth of Lolium multiflorum. Iğdır University Journal of the Institute of Science and Technology 8(1): 309-317.

9. Pavithra GS, Anusha M, Rajyalakshmi M (2012) Effect of Thevetia peruviana extracts on in-vitro and in-vivo cultures of Parthenium hysterophorus L. Journal of Crop Science 3(3): 83.

10. Baličević R, Ravlić M, Knežević M, Marić K, Mikić I (2014) Effect of marigold (Calendula officinalis L.) cogermination, extracts and residues on weed species hoary cress (Cardaria draba (L.) Desv.). Herbologia 14(1): 23-32.

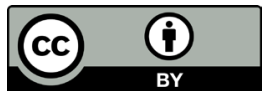

This work is licensed under Creative Commons Attribution 4.0 License DOI: 10.19080/CTBEB.2019.18.555993
11. Kil BS and Youb SL (1987) Allelopathic effects of Chrysanthemum morifolium on germination and growth of several herbaceous plants. Journal of chemical ecology 13(2): 299-308.

12. Khan EA, Khakwani AA, Ghazanfarullah A (2015) Effects of allelopathic chemicals extracted from various plant leaves on weed control and wheat crop productivity. Pakistan Journal of Botany 47(2): 735-740.

13. Jabran K (2017) Maize allelopathy for weed control. In Manipulation of allelopathic crops for weed control. Springer, Cham, pp. 29-34.

14. Lin D, Sugitomo Y, Dong Y, Terao H, Matsuo M (2006) Natural herbicidal potential of saururaceae (Houttuynia cordata Thunb) dried powders on paddy weeds in transplanted rice. Crop protection 25(10): 11261129.

15. Kole RK, Karmakar PR, Poi R, Mazumdar D (2011) Allelopathic inhibition of teak leaf extract: A potential pre-emergent herbicide. Journal of Crop and weed 7(1): 101-109.

16. Xuan TD, Tsuzuki E, Hiroyuki T, Mitsuhiro M, Khanh TD, et al. (2004) Evaluation on phytotoxicity of neem (Azadirachta indica. A. Juss) to crops and weeds. Crop protection 23(4): 335-345.

17. Alam SM, Ala SA, Azmi AR, Khan MA, Ansari R (2001) Allelopathy and its role in agriculture. Journal of Biological Sciences 1(5): 308-315.

\begin{tabular}{|l|}
\hline \multicolumn{1}{|c|}{ Your next submission with Juniper Publishers } \\
will reach you the below assets \\
- Quality Editorial service \\
- Swift Peer Review \\
- Reprints availability \\
- E-prints Service \\
- Manuscript Podcast for convenient understanding \\
- Global attainment for your research \\
- Manuscript accessibility in different formats \\
( Pdf, E-pub, Full Text, Audio) \\
- Unceasing customer service \\
Track the below URL for one-step submission \\
https://juniperpublishers.com/online-submission.php \\
\hline
\end{tabular}

